Article

\title{
Sustainability of High-Value Timber Species in Mixed Conifer-Broadleaf Forest Managed under Selection System in Northern Japan
}

\author{
Kyaw Thu Moe ${ }^{1,2, *(1)}$ and Toshiaki Owari ${ }^{3}[$ \\ 1 Department of Forest Science, Graduate School of Agricultural and Life Sciences, The University of Tokyo, \\ Tokyo 113-8657, Japan \\ 2 Faculty of Forestry, University of Forestry and Environmental Science, Yezin, Naypyitaw 15013, Myanmar \\ 3 The University of Tokyo Chiba Forest, Graduate School of Agricultural and Life Sciences, The University of \\ Tokyo, Kamogawa, Chiba 299-5503, Japan; owari@uf.a.u-tokyo.ac.jp \\ * Correspondence: kyawthumoe.uof@gmail.com
}

Received: 5 March 2020; Accepted: 23 April 2020; Published: 25 April 2020

check for updates

\begin{abstract}
Understanding the sustainability of high-value timber species in managed forests provides useful information for the management of these species in the long-run. Using nearly 50 years of census data in long-term permanent plots, we investigated the sustainability of three high-value timber species-monarch birch (Betula maximowicziana Regel), castor aralia (Kalopanax septemlobus (Thunb.) Koidz), and Japanese oak (Quercus crispula Blume)-in cool-temperate mixed forest under a selection system in northern Japan. We used stocking, demographic parameters, and species proportions of these species as measures of sustainability. Results showed that the tree density and basal area of the three high-value timber species increased during the study period. Moreover, the kbasal area increment of these species showed an increasing trend across census periods. However, while no significant differences in the tree mortality of these species were observed, the numbers of in-growth fluctuated across census periods. Increasing trends in species proportions of monarch birch and Japanese oak were observed. Even though there were some fluctuations across census periods, especially in smaller diameter classes, diameter distribution curves of high-value timber species followed a reversed J-shaped pattern. The results revealed that the sustainability measures of high-value timber species can be achieved in forest stands managed under single-tree selection system. In addition, the results also indicated the changing structure and composition of the forest stand. The stocking and basal area increment of conifers decreased while those of broadleaves increased. The proportion of conifers decreased to $33.01 \%$ in $2008-2016$ from $48.35 \%$ in $1968-1978$. The results of this study would be useful for adapting silvicultural practices and harvesting practices as well as for simulating various silvicultural and management options for high-value timber species.
\end{abstract}

Keywords: high-value timber species; selection harvesting; mixed forest; long-term permanent plot; forest structure

\section{Introduction}

In uneven-aged mixed conifer-broadleaf forests in northern Japan, monarch birch (Betula maximowicziana Regel), castor aralia (Kalopanax septemlobus (Thunb.) Koidz), and Japanese oak (Quercus crispula Blume) are important producers of high commercial value timber, which is used in the veneer and furniture industries. The supply of high-quality timber from these tree species is exclusively dependent on the cutting of large trees within the mixed forests. Large-sized trees in mixed forests contribute to the structural heterogeneity, dynamics, and functions of the forest ecosystem [1,2], a large fraction of aboveground biomass and carbon storage [3], and play important roles in the rate 
and pattern of natural regeneration [4]. In addition, high-value timber species may be subjected to excessive and illegal logging [5,6], and the number of large-sized high-value trees is declining [7] in many regions of the world. Understanding the sustainability of these species will facilitate forest management, conservation, and the simulation of various silvicultural practices.

The achievement of sustainability from the use of various forest management practices is a central precept of forestry and is therefore central to all silvicultural systems [8]. Uneven-aged forest management or selection system has gained growing interest in many parts of the world due to its stability in forest stand structures [9-12], and there has been increasing criticism for even-aged forestry, wherein the whole forest area is clear-cut and regenerated artificially. Furthermore, sustainable forest management (SFM) has been encouraged as a guiding principle in forest management [13] and uneven-aged forest management is assumed to achieve greater sustainability in forest resource management in comparison with even-aged forest management $[8,14]$. It is sometimes referred to as close-to-nature forest management $[15,16]$, which implies the achievement of a form of silviculture that emulates natural processes resulting in stand structures that are natural, and it promotes natural processes such as soil productivity maintenance, nutrient cycling, and biodiversity [16].

In uneven-aged mixed conifer-broadleaf forests in northern Japan, the selection system has been practiced as a common management system since the early twentieth century [17]. In fact, the selection management system attempts to mimic natural disturbances through the use of various management practices. General expectations of the use of selection management are the increased growth, recruitment, and survival of remaining trees [18]. Several research attempts have been made in different parts of the world to investigate the impacts of selection management on the remaining forest stand demographic parameters, i.e., growth, recruitment, and mortality (e.g., [10,19-21]), as well as species composition and stand structure (e.g., [14,22-24]). Many previous studies in mixed conifer-broadleaf forests in northern Japan have also assessed the impact of selection management on the growth, recruitment, and mortality of the remaining forest stand (e.g., [18,25-28]). However, few studies have examined the sustainability of forest stands, especially high-value timber species. Information on the sustainability of high-value timber species within mixed forests is important for forestry practitioners, especially when the goal of forest management is to manage certain species. Moreover, understanding the sustainability of uneven-aged mixed forests is useful for forest management decision [29] because it helps to determine whether or not a specific stand structure should be maintained [30,31].

The assessment of sustainability in uneven-aged mixed forest is relatively difficult because forests are slow growing and it may take several decades to examine the long-term impacts of any given forest management activities. It requires criteria and indicators that can be measured during stand development [8] after forest management activities. The availability of long term forest measurement data, therefore, is an important source of information [32], not only for providing information of forest stand dynamics but also to assess the sustainability of forest stands subjected to various natural and anthropogenic disturbances.

The parameters derived from long-term forest measurement data would be useful for assessing the sustainability of a forest management system. O'Hara et al. [8] compared forest stand parameters such as stocking (tree density and basal area), species diversity, stand structure, and increment between even-aged forest and a selection system in Central Europe as measures of sustainability using over 90 years of forest measurement data. In addition, Schuler [21] examined the species composition, diversity, and growth of tree species in mixed mesophytic forest in the USA after 50 years of partial harvesting. In mixed conifer-broadleaf forest in northern Japan, Yoshida et al. [18] assessed the dynamics of a forest stand after 20 years of selection harvest. However, these studies examined long term changes in the stocking and demographic parameters of major tree species or stand level stocking, species diversity, and stand structure. The sustainability of high-value timber species after selection harvest has not been widely studied. Understanding the sustainability of high-value timber species will be useful for the reliable application of a selection system and species-specific forest management or a single-tree management system, which was recommended in previous studies (e.g., [7,33]). 
The aim of this study is, therefore, to assess the sustainability of high-value timber species in mixed forests managed under selection systems. Using 48 years of measurement data, we derived the stocking, demographic parameters, and species proportion of high-value timber species as measures of sustainability. To reach the objective, firstly, we assessed the changes in stocking and demographic characteristics of high-value timber species over time. Secondly, the changes in the species proportion of high-value timber species were assessed. In addition, we also showed how the forest stand structure was changing by assessing the sustainability measures of all conifer and broadleaf species.

\section{Materials and Methods}

\subsection{Study Site}

This study was conducted in the University of Tokyo Hokkaido Forest (UTHF) (43 ${ }^{\circ} 10-20^{\prime}$ N, $142^{\circ} 18-40^{\prime}$ E, 190-1459 $\mathrm{m}$ a.s.1.), which has an area of 22,717 ha. The UTHF is located in Furano City, central Hokkaido Island in northern Japan (Figure 1). The mean annual temperature and annual precipitation of UTHF are $6.3^{\circ} \mathrm{C}$ and $1210 \mathrm{~mm}$, respectively [33]. The ground is covered with snow from late November to early April with a depth of approximately $1 \mathrm{~m} \mathrm{[34].} \mathrm{Typical} \mathrm{vegetation} \mathrm{in} \mathrm{the} \mathrm{UTHF}$ is uneven-aged mixed forests where conifers and broadleaf tree species are the main vegetation cover. The predominant tree species include Sakhalin fir (Abies sachalinensis), Yezo spruce (Picea jezoensis), Japanese linden (Tilia japonica), and painted maple (Acer pictum var. mono) [35]. The forest floor is often occupied by evergreen dwarf bamboo (Sasa senanensis and Sasa kurilensis).

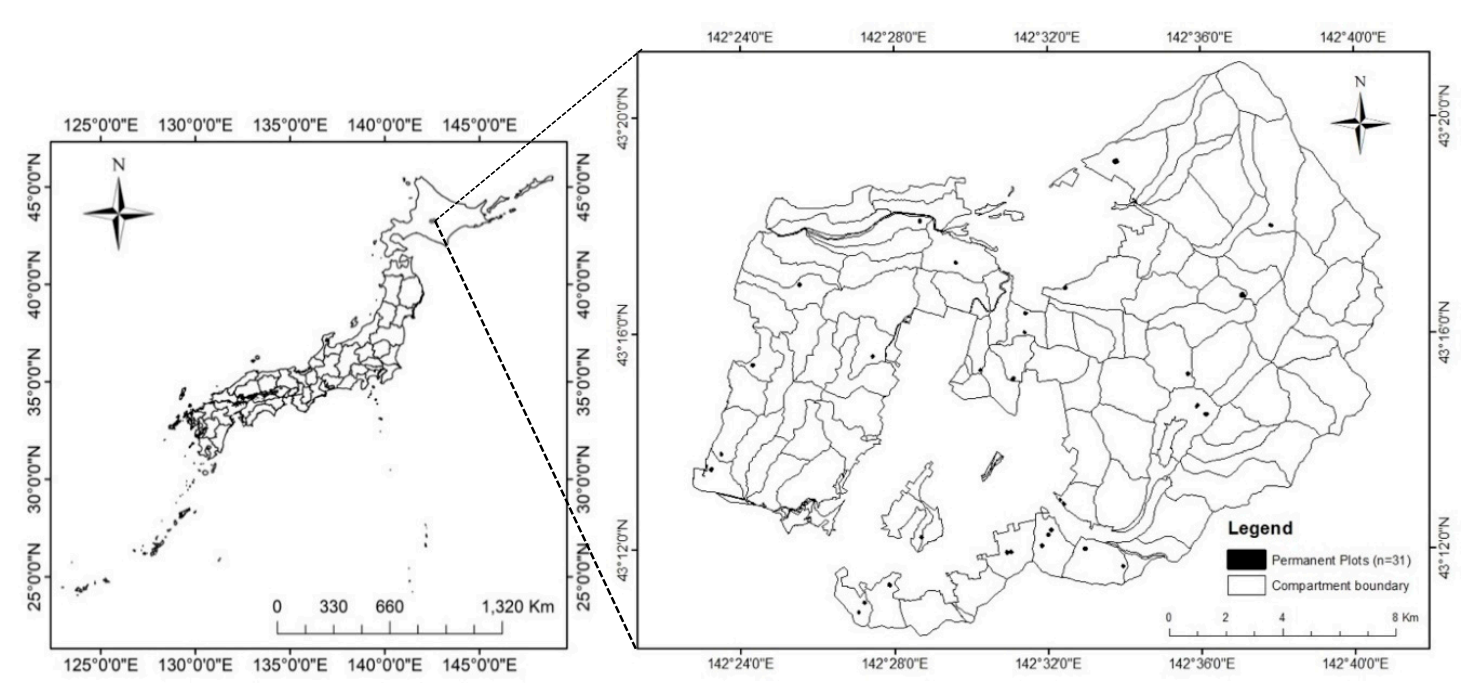

Figure 1. Location of the permanent plots.

\subsection{Brief Overview of Single-Tree Selection System at the UTHF}

Long-term and large-scale experiments of stand-based forest management system have been conducted since 1958 in the UTHF [35]. Single-tree selection harvest, in which trees are periodically selected and harvested from a large area with cutting cycle of 15 to 20 years and a tree removal rate of $10 \%-17 \%$, has been implemented as the main silvicultural system in the UTHF [33]. General guidelines for tree marking for selection harvest include tree vitality potential, low quality trees that restrict the growth of seedlings and juveniles, trees with low stem quality, large-sized trees with volume increment that cannot be expected to, or have wood quality that will be deteriorated, or thinning to control stand density, etc. Tree marking operations are conducted by technical staff with long-term operational experiences in tree marking. Attention was paid to be spatially unbiased when marking trees for selection harvest [36]. Larger trees are more likely to be marked than smaller ones, while dominant specie, i.e., A. sachalinensis, is more likely to be selected in tree marking operations [36] even though there is no long-term goal to change the species composition of forest stand. Logging operations 
typically use felling with chainsaws and skidding of the felled stems by a winch-equipped crawler tractor [27].

\subsection{Data}

Permanent plots were established throughout the UTHF to record long-term growth and stand development for the management of uneven-aged mixed forests [37]. A stratified purposive sampling scheme was employed for the plot establishment to represent the major stand types, soil, and terrain conditions [38]. Harvesting and management of forest stands were monitored using permanent plot data by assessing temporal dynamics of stand structure and fluctuation of forest resources. Within these plots, diameter at breast height $(\mathrm{DBH})$ measurements of all trees with $\mathrm{DBH} \geq 5 \mathrm{~cm}$ are performed by UTHF staff at regular, in most cases, 5-years interval with $0.1 \mathrm{~cm}$ precision. All trees were tagged with identification numbers (IDs) on metal plates nailed to steel rods to ensure that DBH measurements were repeated on the same trees. Plot data included species, DBH, survival status, and harvest of all trees with $\mathrm{DBH} \geq 5.0 \mathrm{~cm}$.

In the current study, we used tree census data from 31 permanent sample plots (plot sizes range from 0.22 to $1.00 \mathrm{ha}$ ) in the UTHF where the selection system has been implemented. We used the tree census data of the plots measured between 1968 and 2016. Measurement intervals ranged from 3 to 12 years, and the number of measurements in the plots ranged from 8 to 11. The plots were subjected to selection harvest 3 to 5 times during the observation period.

\subsection{Measures of Sustainability}

In order to assess the sustainability of high-value timber species, we considered the stocking and demographic characteristics, and species proportion, as suggested by O'Hara et al. [8]. Stocking included the tree density (number of trees per hectare- $\mathrm{N}$, tree ha ${ }^{-1}$ ) and basal area per hectare $\left(\mathrm{BA}, \mathrm{m}^{2} \mathrm{ha}^{-1}\right)$. Demographic characteristics included basal area increment (BAI, $\left.\mathrm{m}^{2} \mathrm{ha}^{-1} \mathrm{yr}^{-1}\right)$; number of recruitment or in-growth (N-rec, tree ha ${ }^{-1}$ ), and number of tree mortality (N-mor, tree ha ${ }^{-1}$ ). BAI was calculated based on two consecutive measurements of DBH. We excluded negative BAI values in the analysis, as these were assumed to be measurement errors. We also excluded dead trees in the second measurement of two consecutive measurements in BAI calculations. N-rec was calculated as the number of trees that were entered into the minimum $5.0 \mathrm{~cm} \mathrm{DBH}$ in the second measurement of two consecutive measurements. We considered the dead trees in the second measurement of two consecutive measurements as N-mor, and we counted the number of dead trees between two measurements. In addition, we compared the changes in N, BA, and BAI to understand the general temporal trend of the study forest stand. Changes in the species proportions of high-value timber species as well as the proportion of conifer and broadleaf trees were also analyzed. We also assessed the selection harvest of conifer and broadleaf trees across the census periods.

\subsection{Data Analysis}

For simplicity in the comparison of sustainability measures, we divided the measurement records into 5 census periods; I (1968-1978), II (1978-1988), III (1988-1998), IV (1998-2008), and V (2008-2016). The year of measurement was used to determine the census periods, i.e., all censuses that were measured in the years between 1968 and 1978 were assumed as period I. We tested stand level changes in stocking, demographic characteristics, and proportion of high-value timber species using the Friedman test. For significant Friedman test results $(p<0.05)$, a post-hoc test was applied to detect which census periods showed significant increase or decrease in stocking, demographic characteristics, or species proportion. A linear mixed effect model was used to quantify whether the stocking, demographic characteristics, and species proportion increased or decreased over time. The model form can be described as the following equation:

$$
Y_{i j}=\mathrm{a}_{0}+\mathrm{a}_{1} X_{i j}+\text { plot }_{j}+\varepsilon_{i j}
$$


where $Y_{i j}$ represents the sustainability measures mentioned in Section 2.3 for census year $i$ in plot $j$, and $X_{i j}$ is census year $i$ in plot $j . a_{0}$ and $a_{1}$ are fixed effect parameters, and plot is $_{j}$ the random effect parameter for plot $j$. The symbol $\varepsilon_{i j}$ stands for residuals. The significant slope coefficient $(p<0.05)$ was used as an indicator of either positive or negative trends of the forest characteristics mentioned in Section 2.3 over time [8]. All statistical analysis were carried out in R software version 3.6.1 [39].

\section{Results}

\subsection{Changes in Stocking of High-Value Timber Species}

Changes in $\mathrm{N}$ and BA are shown in Table 1. Diameter distribution of high-value timber species are shown in Figure 2. During the 48-year period, the $\mathrm{N}$ of monarch birch significantly increased (Friedman test, $p<0.05$ ) in the study permanent plots with the mean $\mathrm{N}$ of the last census period (2008-2016) being significantly higher than in the first two census periods (Table 1). The BA of monarch birch also increased, reaching the highest in the last period. Monarch birch BA in the last two periods was significantly higher than in the previous three periods. The $\mathrm{N}$ of castor aralia did not increase or decrease significantly $(p=0.75)$ in any period. However, the BA of castor aralia increased significantly $(p<0.001)$. The $\mathrm{N}$ of Japanese oak did not significantly increase in the first three periods, but it significantly increased in the last two periods. Similar to other two species, the highest BA of Japanese oak occurred in the last period. According to the mixed effect model, the slope coefficients for $\mathrm{N}$ and BA for all species showed significant positive trends over time (Table 2).

Table 1. Stocking of high-value timber species (mean (standard deviation)).

\begin{tabular}{|c|c|c|c|c|c|c|}
\hline \multirow{2}{*}{$\begin{array}{l}\text { Census } \\
\text { Periods }\end{array}$} & \multicolumn{2}{|c|}{ Monarch Birch } & \multicolumn{2}{|c|}{ Castor Aralia } & \multicolumn{2}{|c|}{ Japanese Oak } \\
\hline & Density (N/ha) & $\begin{array}{c}\text { Basal Area } \\
\left(\mathrm{m}^{2} / \mathrm{ha}\right)\end{array}$ & Density (N/ha) & $\begin{array}{c}\text { Basal Area } \\
\left(\mathrm{m}^{2} / \mathrm{ha}\right)\end{array}$ & Density (N/ha) & $\begin{array}{c}\text { Basal Area } \\
\left(\mathrm{m}^{2} / \mathrm{ha}\right)\end{array}$ \\
\hline I & $3.83(5.80)^{\mathrm{a}}$ & $0.13(0.20)^{a}$ & $19.26(14.51)^{\mathrm{a}}$ & $0.30(0.34)^{\mathrm{a}}$ & $11.03(15.92)^{\mathrm{a}}$ & $0.55(0.99)^{a}$ \\
\hline II & $3.59(4.77)^{\mathrm{a}}$ & $0.16(0.22)^{\mathrm{a}}$ & $21.18(16.85)^{a}$ & $0.40(0.37)^{\mathrm{ab}}$ & $11.64(15.39)^{\mathrm{a}}$ & $0.53(0.85)^{b}$ \\
\hline III & $5.49(7.58)^{a b}$ & $0.17(0.25)^{a}$ & $21.79(14.77)^{a}$ & $0.43(0.39)^{b}$ & $12.54(15.25)^{a}$ & $0.48(0.84)^{b}$ \\
\hline IV & $11.37(18.5)^{a b}$ & $0.20(0.26)^{b}$ & $24.39(17.25)^{\mathrm{a}}$ & $0.48(0.41)^{\mathrm{c}}$ & $16.26(16.17)^{b}$ & $0.62(0.95)^{c}$ \\
\hline $\mathrm{V}$ & $11.24(20.61)^{b}$ & $0.26(0.33)^{c}$ & $23.39(17.43)^{\mathrm{a}}$ & $0.56(0.40)^{d}$ & $15.05(16.48)^{b}$ & $0.68(1.08)^{d}$ \\
\hline
\end{tabular}

Note: Census periods with different letters show significant differences $(p<0.05)$.

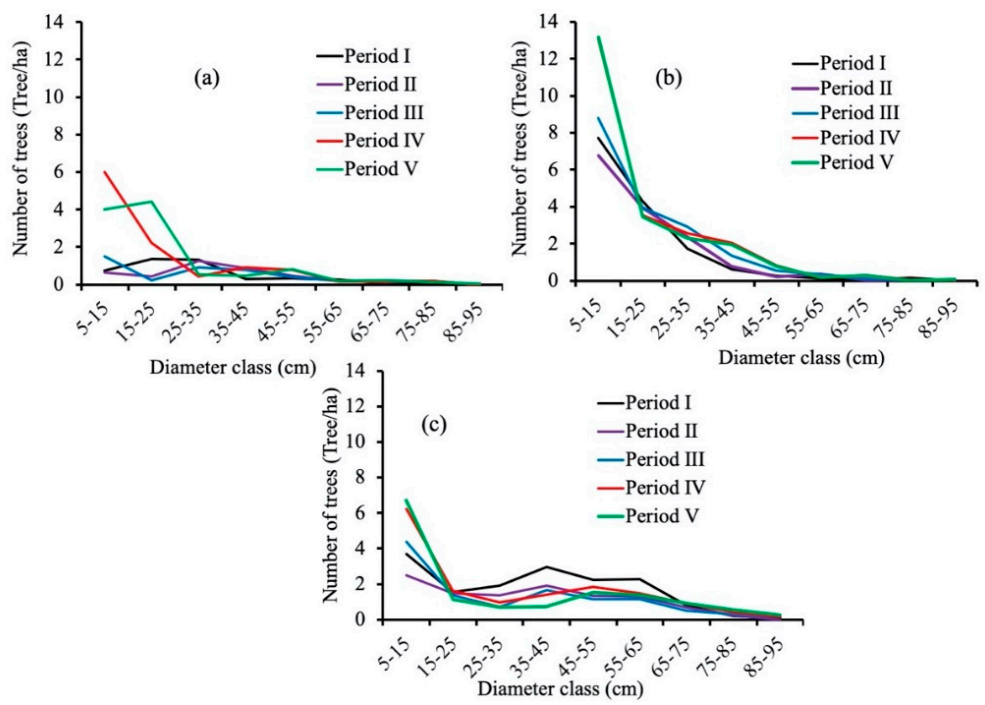

Figure 2. Diameter distribution of high-value timber species across census periods. (a) Monarch birch, (b) Castor aralia, and (c) Japanese oak. Number of trees indicate the mean values. 
Table 2. The results of linear mixed-effect models showing the general temporal trend of stocking, demography and diversity indices for high-value timber species.

\begin{tabular}{ccccccc}
\hline \multirow{2}{*}{ Variable } & \multicolumn{2}{c}{ Monarch Birch } & \multicolumn{2}{c}{ Castor Aralia } & \multicolumn{2}{c}{ Japanese Oak } \\
\cline { 2 - 6 } & $\mathbf{a}_{\mathbf{0}}$ & $\mathbf{a}_{\mathbf{1}}$ & $\mathbf{a}_{\mathbf{0}}$ & $\mathbf{a}_{\mathbf{1}}$ & $\mathbf{a}_{\mathbf{0}}$ & $\mathbf{a}_{\mathbf{1}}$ \\
\hline Tree density (N/ha) & $-477.64^{* * *}$ & $0.24^{* * *}$ & $-207.00^{*}$ & $0.11^{*}$ & $-359.84^{* * *}$ & $0.19^{* * *}$ \\
Basal area $\left(\mathrm{m}^{2} / \mathrm{ha}\right)$ & $-6.13^{* * *}$ & $0.003^{* * *}$ & $-0.11^{* * *}$ & $0.006^{* * *}$ & $-0.11^{* * *}$ & $0.006^{* * *}$ \\
Basal area increment & $-0.27^{* * *}$ & $0.0001^{* * *}$ & $-0.21^{* * *}$ & $0.0001^{*}$ & $-0.19^{* * *}$ & $0.0001^{* *}$ \\
$\left(\mathrm{~m}^{2} / \mathrm{ha} / \mathrm{year}\right)$ & $-32.57^{* *}$ & $0.02^{* *}$ & $-10.04^{\mathrm{ns}}$ & $0.01^{\mathrm{ns}}$ & $-24.77^{*}$ & $0.012^{*}$ \\
Mortality (N/ha) & $-45.43^{\mathrm{ns}}$ & $0.02^{\mathrm{ns}}$ & $27.52^{\mathrm{ns}}$ & $-0.01^{\mathrm{ns}}$ & $-34.63^{\mathrm{ns}}$ & $0.02^{\mathrm{ns}}$ \\
In-growth (N/ha) & $-45.87^{* * *}$ & $0.02^{* * *}$ & $-5.29^{\mathrm{ns}}$ & $0.004^{\mathrm{ns}}$ & $-27.78^{* * *}$ & $0.015^{* * *}$ \\
Species proportion $(\%)$ & &
\end{tabular}

Significant code: ${ }^{*} p<0.05,{ }^{* *} p<0.01,{ }^{* * *} p<0.001$. ns stands for non-significant. $\mathrm{a}_{0}$ and $\mathrm{a}_{1}$ are fixed-effect parameters of Equation (1).

For the purpose of comparison, Figure 3 shows changes in the $\mathrm{N}$ and BA of forest stand, conifer, and broadleaf across census periods. The Friedman test showed significant differences in both $\mathrm{N}$ and BA over time $(p<0.05)$. In addition, Figure 3 also shows the changes in the $\mathrm{N}$ and BA of conifer and broadleaf species during the 48-year period. The figure shows increasing trends in broadleaf $\mathrm{N}$ and BA, while decreasing trends can be observed for conifer $\mathrm{N}$ and BA. Friedman test also showed significant differences $(p<0.05)$. The results of the mixed effect model also confirmed the significant and positive trends in $\mathrm{N}$ and $\mathrm{BA}$ over time. However, significant and negative trends were observed for conifer $\mathrm{N}$ and BA, while a positive trend was observed for broadleaf species (Table 3).

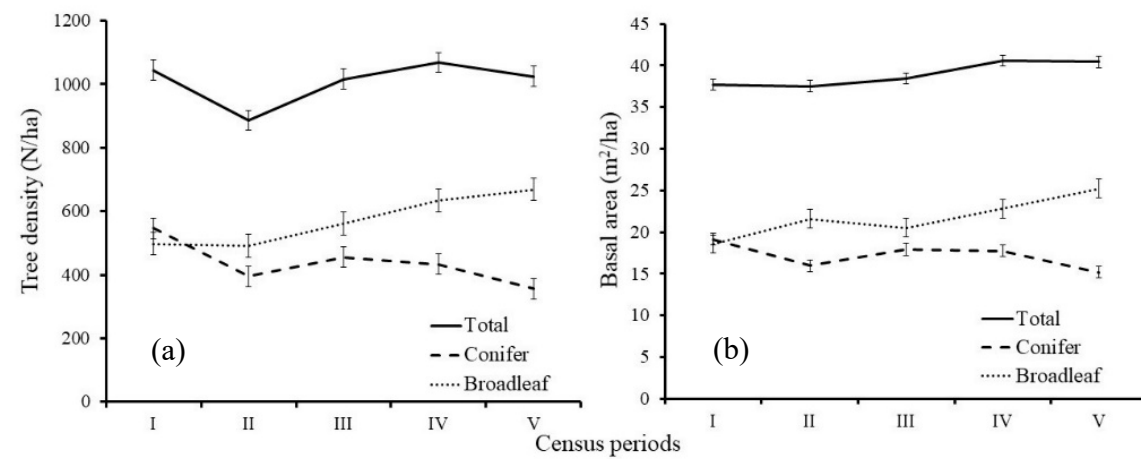

Figure 3. Development of stand level density (a), and basal area (b) of all species (mean (standard error)).

Table 3. The results of linear mixed-effect models showing the general temporal trend of stocking and demography of forest stand.

\begin{tabular}{ccccccc}
\hline \multirow{2}{*}{ Variable } & \multicolumn{2}{c}{ Total } & \multicolumn{2}{c}{ Conifer } & \multicolumn{2}{c}{ Broadleaf } \\
\cline { 2 - 7 } & $\mathbf{a}_{\mathbf{0}}$ & $\mathbf{a}_{\mathbf{1}}$ & $\mathbf{a}_{\mathbf{0}}$ & $\mathbf{a}_{\mathbf{1}}$ & $\mathbf{a}_{\mathbf{0}}$ & $\mathbf{a}_{\mathbf{1}}$ \\
\hline Tree density (N/ha) & $-3114.45^{*}$ & $2.07^{* *}$ & $6423.42^{* * *}$ & $-3.01^{* * *}$ & $-9561.88^{* * *}$ & $5.08^{* * *}$ \\
Basal area (m $/ \mathrm{ha})$ & $-164.20^{* * *}$ & $0.10^{* * *}$ & $98.31^{* * *}$ & $-0.04^{* * *}$ & $-262.40^{* * *}$ & $0.14^{* * *}$ \\
Basal area increment & $-4.48^{* * *}$ & $0.002^{* * *}$ & $2.58^{* *}$ & $-0.001^{*}$ & $-7.09^{* * *}$ & $0.004^{* * *}$ \\
(m $\mathrm{m}^{\text {/ha/year) }}$ & $-1056.16^{\mathrm{ns}}$ & $0.57^{\mathrm{ns}}$ & $186.50^{\mathrm{ns}}$ & $-0.08^{\mathrm{ns}}$ & $-1240.98^{*}$ & $0.65^{*}$ \\
In-growth (N/ha) & $-1550.45^{* *}$ & $0.82^{* *}$ & $313.36^{\mathrm{ns}}$ & $-0.14^{\mathrm{ns}}$ & $-1859.66^{* * *}$ & $0.95^{* * *}$ \\
Mortality (N/ha) & & & $664.93^{* * *}$ & $-0.31^{* * *}$ & $-564.93^{* * *}$ & $0.31^{* * *}$ \\
\hline Species proportion (\%) & & & &
\end{tabular}

Significant code: ${ }^{*} p<0.05,{ }^{* *} p<0.01,{ }^{* * *} p<0.001$. ns stands for non-significant. $\mathrm{a}_{0}$ and $\mathrm{a}_{1}$ are fixed-effect parameters of Equation (1).

\subsection{Changes in the Demographic Characteristics of High-Value Timber Species}

Changes in the demographic parameters of high-value timber species are shown in Table 4. The BAI of monarch birch in the last two census periods was significantly higher than the first three periods $(p<0.001)$. A significant higher BAI of Japanese oak $(p<0.001)$ was found in the last two 
measurement periods with the highest increment in the fourth census period. An increasing trend in the BAI of castor aralia was also observed. The mixed effect model also revealed a positive slope coefficient for the BAI of all species (Table 2). The Friedman test showed no statistically significant difference between census periods for N-mor (Table 4). However, a significant positive slope was observed for monarch birch and Japanese oak, meaning that the N-mor of monarch birch and Japanese oak may be likely to increase over time (Table 2). In all target species, an increased N-rec was observed in the second, third, and fourth census periods. However, a significant decline in the N-rec was observed in the last census period (Table 4), and no significant positive or negative slope coefficients were observed for any species in the results of the mixed effect model (Table 2).

Table 4. Demographic characteristics of high-value timber species (mean (standard deviation)).

\begin{tabular}{|c|c|c|c|c|c|c|c|c|c|}
\hline \multirow{2}{*}{$\begin{array}{l}\text { Census } \\
\text { Period }\end{array}$} & \multicolumn{3}{|c|}{ Monarch Birch } & \multicolumn{3}{|c|}{ Castor Aralia } & \multicolumn{3}{|c|}{ Japanese Oak } \\
\hline & $\begin{array}{c}\text { BAI } \\
\left(\mathrm{m}^{2} / \mathrm{ha} / \mathrm{yr}\right)\end{array}$ & $\begin{array}{l}\text { Mortality } \\
\text { (N/ha) }\end{array}$ & $\begin{array}{l}\text { In-Growth } \\
\text { (N/ha) }\end{array}$ & $\begin{array}{c}\text { BAI } \\
\left(\mathrm{m}^{2} / \mathrm{ha} / \mathrm{yr}\right)\end{array}$ & $\begin{array}{l}\text { Mortality } \\
\text { (N/ha) }\end{array}$ & $\begin{array}{c}\text { In-Growth } \\
\text { (N/ha) }\end{array}$ & $\begin{array}{c}\text { BAI } \\
\left(\mathrm{m}^{2} / \mathrm{ha} / \mathrm{yr}\right)\end{array}$ & $\begin{array}{l}\text { Mortality } \\
\text { (N/ha) }\end{array}$ & $\begin{array}{c}\text { In-Growth } \\
\text { (N/ha) }\end{array}$ \\
\hline I & $\begin{array}{c}0.0023 \\
(0.004)^{\mathrm{a}}\end{array}$ & $\begin{array}{c}0.21 \\
(0.92)^{\mathrm{a}}\end{array}$ & $\begin{array}{c}0.10 \\
(0.65)^{\mathrm{a}}\end{array}$ & $\begin{array}{c}0.0053 \\
(0.006)^{a}\end{array}$ & $\begin{array}{c}1.56 \\
(3.29)^{a}\end{array}$ & $\begin{array}{c}0.93 \\
(2.32)^{a}\end{array}$ & $\begin{array}{c}0.0057 \\
(0.009)^{\mathrm{a}}\end{array}$ & $\begin{array}{c}0.07 \\
(0.45)^{\mathrm{a}}\end{array}$ & $0.00^{\mathrm{a}}$ \\
\hline II & $\begin{array}{c}0.0021 \\
(0.003)^{a}\end{array}$ & $\begin{array}{c}0.39 \\
(1.07)^{\mathrm{a}}\end{array}$ & $\begin{array}{c}0.13 \\
(0.90)^{\mathrm{a}}\end{array}$ & $\begin{array}{c}0.0074 \\
(0.007)^{a b}\end{array}$ & $\begin{array}{c}2.37 \\
(4.81)^{\mathrm{a}}\end{array}$ & $\begin{array}{c}3.19 \\
(7.45)^{b}\end{array}$ & $\begin{array}{c}0.0057 \\
(0.010)^{\mathrm{a}}\end{array}$ & $\begin{array}{c}0.46 \\
(1.48)^{\mathrm{a}}\end{array}$ & $\begin{array}{c}1.25 \\
(4.39)^{b}\end{array}$ \\
\hline III & $\begin{array}{c}0.0027 \\
(0.004)^{\mathrm{a}}\end{array}$ & $\begin{array}{c}0.16 \\
(0.76)^{\mathrm{a}}\end{array}$ & $\begin{array}{c}1.81 \\
(4.98)^{b}\end{array}$ & $\begin{array}{c}0.0080 \\
(0.008)^{b}\end{array}$ & $\begin{array}{c}2.40 \\
(4.14)^{\mathrm{a}}\end{array}$ & $\begin{array}{c}3.95 \\
(6.94)^{b}\end{array}$ & $\begin{array}{c}0.0062 \\
(0.010)^{a}\end{array}$ & $\begin{array}{c}0.15 \\
(0.58)^{\mathrm{a}}\end{array}$ & $\begin{array}{c}1.77 \\
(3.24)^{b}\end{array}$ \\
\hline IV & $\begin{array}{c}0.0058 \\
(0.009)^{b}\end{array}$ & $\begin{array}{c}0.39 \\
(1.18)^{\mathrm{a}}\end{array}$ & $\begin{array}{c}2.86 \\
(8.01)^{b}\end{array}$ & $\begin{array}{c}0.0099 \\
(0.007)^{\mathrm{c}}\end{array}$ & $\begin{array}{c}1.72 \\
(3.34)^{\mathrm{a}}\end{array}$ & $\begin{array}{c}2.89 \\
(5.75)^{\mathrm{ab}}\end{array}$ & $\begin{array}{c}0.0092 \\
(0.012)^{b}\end{array}$ & $\begin{array}{c}0.52 \\
(1.60)^{\mathrm{a}}\end{array}$ & $\begin{array}{c}1.65 \\
(2.64)^{b}\end{array}$ \\
\hline V & $\begin{array}{c}0.0069 \\
(0.012)^{b}\end{array}$ & $\begin{array}{c}0.96 \\
(2.21)^{\mathrm{a}}\end{array}$ & $\begin{array}{c}0.28 \\
(1.51)^{\mathrm{a}}\end{array}$ & $\begin{array}{c}0.0094 \\
(0.008)^{b c}\end{array}$ & $\begin{array}{c}2.47 \\
(4.19)^{\mathrm{a}}\end{array}$ & $\begin{array}{c}0.94 \\
(2.28)^{\mathrm{a}}\end{array}$ & $\begin{array}{c}0.0078 \\
(0.012)^{b}\end{array}$ & $\begin{array}{c}0.53 \\
(1.03)^{\mathrm{a}}\end{array}$ & $\begin{array}{c}0.61 \\
(1.82)^{a}\end{array}$ \\
\hline
\end{tabular}

Note: Census periods with different letters show significant difference $(p<0.05)$.

Figure 4 shows changes in the BAI, N-mor and N-rec of all species. The total BAI of all species showed no statistically significant difference in the first three census periods. However, it was significantly higher in the last two periods than in the first three periods $(p<0.05)$. The total BAI of broadleaf species increased while the conifer BAI decreased in the last census period. These results are also confirmed by the results of the mixed effect model in which a significant negative slope was observed for conifer and a positive slope was observed for broadleaf. The broadleaf N-rec that entered into the $5.0 \mathrm{~cm} \mathrm{DBH}$ was higher than that of the conifer N-rec. For both conifer and broadleaf species, the N-rec decreased from the third census period (Figure 4). The number of total N-mor significantly increased since third census period. When comparing the conifer and broadleaf N-mor, the broadleaf $\mathrm{N}$-mor increased from the third census period. However, there was no significant increase or decrease in conifer $\mathrm{N}$-mor after the third census period. The mixed effect model also revealed an increase in the total N-mor over time. In addition, the broadleaf N-mor also increased over time.

\subsection{Changes in Species Proportion of High-Value Timber Species}

Table 5 shows the changes in species proportion of high-value timber species. Significant differences in the proportion of Japanese oak were observed $(p<0.001)$, while no significant differences were observed for monarch birch $(p<0.22)$ or castor aralia $(p<0.31)$ across census periods. However, a significant positive trend in the monarch birch proportion was observed over time (Table 2). Similarly, Table 2 shows a significant positive trend in the Japanese oak proportion. Table 5 also shows the changes in the proportion of conifer and broadleaf across census periods. The proportion of conifer declined after the first census period while that of broadleaf increased after the first period. These trends were also confirmed by the positive coefficients of mixed-effect models (Table 2). 


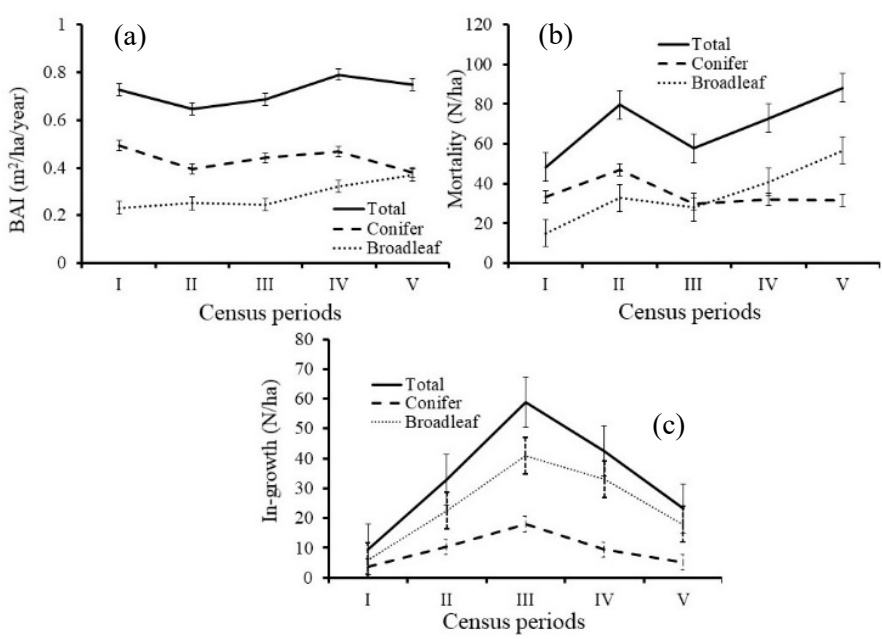

Figure 4. Development of demographic parameters of all species (mean (standard error)). (a) Basal area increment ( $\mathrm{m}^{2} /$ ha/year), (b) Mortality (N/ha), and (c) In-growth (N/ha).

Table 5. Changes in species proportion (\%) of high-value timber species.

\begin{tabular}{cccccc}
\hline Census Period & Monarch Birch & Castor Aralia & Japanese Oak & Conifer & Broadleaf $^{\text {Caf }}$ \\
\hline I & $0.37(0.48)^{\mathrm{a}}$ & $1.87(1.38)^{\mathrm{a}}$ & $1.01(1.43)^{\mathrm{a}}$ & $48.35(22.89)^{\mathrm{a}}$ & $51.65(22.89)^{\mathrm{a}}$ \\
II & $0.41(0.48)^{\mathrm{a}}$ & $2.37(1.72)^{\mathrm{a}}$ & $1.25(1.64)^{\mathrm{b}}$ & $41.38(20.17)^{\mathrm{a}}$ & $58.62(20.17)^{\mathrm{ab}}$ \\
III & $0.58(0.82)^{\mathrm{a}}$ & $2.15(1.30)^{\mathrm{a}}$ & $1.22(1.56)^{\mathrm{ab}}$ & $41.43(19.76)^{\mathrm{b}}$ & $58.56(19.76)^{\mathrm{bc}}$ \\
IV & $1.13(1.72)^{\mathrm{a}}$ & $2.24(1.38)^{\mathrm{a}}$ & $1.46(1.44)^{\mathrm{bc}}$ & $38.13(18.69)^{\mathrm{bc}}$ & $61.84(18.69)^{\mathrm{cd}}$ \\
V & $1.10(1.79)^{\mathrm{a}}$ & $2.23(1.39)^{\mathrm{a}}$ & $1.38(1.34)^{\mathrm{c}}$ & $33.01(14.30)^{\mathrm{c}}$ & $66.99(14.30)^{\mathrm{d}}$ \\
\hline
\end{tabular}

Note: Census periods with different letters show significant difference $(p<0.05)$.

\subsection{Selection Harvest}

Table 6 shows the total $\mathrm{N}$ and BA harvest of high-value timber species. The small $\mathrm{N}$ and BA of high-value timber species were harvested during the 48-year period. Table 7 shows the total N and BA harvest of conifer and broadleaf across census periods. The number of broadleaf trees harvested in the first census period was higher than the number of conifer trees harvested. Starting from the second census period, more conifer trees than broadleaf trees were harvested. According to Table 6, the BA harvest for conifer was larger than the BA harvest for broadleaf in all periods. The BA harvest for broadleaf in the first census period was significantly higher than in the later four periods, with the lowest BA harvest occurring in the third period. The largest BA harvest for conifer occurred in the fourth census period.

Table 6. Harvest of high-value timber species (mean (standard deviation)).

\begin{tabular}{|c|c|c|c|c|c|c|}
\hline \multirow{2}{*}{$\begin{array}{l}\text { Census } \\
\text { Periods }\end{array}$} & \multicolumn{2}{|c|}{ Monarch Birch } & \multicolumn{2}{|c|}{ Castor Aralia } & \multicolumn{2}{|c|}{ Japanese Oak } \\
\hline & $\begin{array}{c}\text { Number } \\
\text { (N/ha) }\end{array}$ & BA $\left(m^{2} / h a\right)$ & $\begin{array}{c}\text { Number } \\
\text { (N/ha) }\end{array}$ & BA $\left(m^{2} / h a\right)$ & $\begin{array}{l}\text { Number } \\
\text { (N/ha) }\end{array}$ & BA (m²/ha) \\
\hline I & $0.50(2.09)^{\mathrm{a}}$ & $0.04(0.25)^{\mathrm{a}}$ & $2.20(5.36)^{a}$ & $0.02(0.04)^{a}$ & $0.47(1.50)^{\mathrm{a}}$ & $0.03(0.18)^{a}$ \\
\hline II & $0.04(0.26)^{\mathrm{a}}$ & $0.01(0.07)^{a}$ & $0.28(0.94)^{b}$ & $0.007(0.03)^{a b}$ & $0.28(1.16)^{a b}$ & $0.09(0.38)^{a b}$ \\
\hline III & $0.05(0.37)^{\mathrm{a}}$ & $0.006(0.05)^{a}$ & $0.61(3.17)^{b c}$ & $0.012(0.05)^{a b}$ & $0.04(0.32) b c$ & $0.0003(0.002)^{b}$ \\
\hline IV & $0.06(0.52)^{\mathrm{a}}$ & $0.003(0.02)^{\mathrm{a}}$ & $0.04(0.28)^{c}$ & $0.002(0.01)^{b}$ & $0.04(0.31) b c$ & $0.0001(0.001)^{b}$ \\
\hline $\mathrm{V}$ & $0^{\mathrm{a}}$ & $0^{\mathrm{a}}$ & $0.31(1.05) b c$ & $0.03(0.11)^{b}$ & $0.06(0.45)^{c}$ & $0.02(0.15)^{b}$ \\
\hline
\end{tabular}

Note: Census periods with different letters show significant difference $(p<0.05)$. 
Table 7. Harvest of conifer and broadleaf (mean (standard deviation)).

\begin{tabular}{|c|c|c|c|c|}
\hline \multirow{2}{*}{ Census Period } & \multicolumn{2}{|c|}{ Conifer Harvest } & \multicolumn{2}{|c|}{ Broadleaf Harvest } \\
\hline & Number (N/ha) & $\mathrm{BA}\left(\mathrm{m}^{2} / \mathrm{ha}\right)$ & Number (N/ha) & $\mathrm{BA}\left(\mathrm{m}^{2} / \mathrm{ha}\right)$ \\
\hline I & $32.87(51.11)^{\mathrm{a}}$ & $1.87(2.60)^{a b}$ & $55.25(82.84)^{\mathrm{a}}$ & $1.31(2.08)^{\mathrm{a}}$ \\
\hline II & $11.07(23.56)^{b c}$ & $0.73(1.43) b c$ & $10.33(20.58)^{a b}$ & $0.47(0.96)^{a b c}$ \\
\hline III & $14.16(30.15)^{c}$ & $1.10(2.03)^{\mathrm{c}}$ & $7.98(32.31)^{c}$ & $0.26(0.70)^{c}$ \\
\hline IV & $16.87(26.22)^{a b}$ & $2.02(2.87)^{a}$ & $4.58(6.94) b c$ & $0.41(0.73)^{a b}$ \\
\hline $\mathrm{V}$ & $9.92(18.38) b c$ & $1.37(2.40)^{a b c}$ & $4.72(9.31) \mathrm{bc}$ & $0.34(0.78) b c$ \\
\hline
\end{tabular}

Note: Census periods with different letters show significant difference $(p<0.05)$.

\section{Discussion}

In this study, we investigated the long-term changes in stocking, demographic characteristics, and species proportion of high-value timber species as measures of sustainability. We used these parameters as criteria and indicators to evaluate the sustainability of high-value timber species as proposed by O'Hara et al. [8]. However, they used these criteria and indicators to evaluate the stand level sustainability of even-aged and uneven-aged forest management. The changes or consistency of these parameters would be useful for establishing sustainable forest management by adjusting the tree marking for harvesting.

The main common characteristics of the targeted high-value timber species in this study were increase in $\mathrm{N}$ and BA. The increasing trend was also observed in the total $\mathrm{N}$ and total BA of forest stands. An increase in the $\mathrm{N}$ of forest stands managed under the selection system has occurred in the last few decades in other parts of the world with different environment and forest types. For example, Klopcic et al. [20] found an increased total number of trees in their study in Slovenia. Compared with an unmanaged stand, a higher mean density and basal area in the managed stand was also reported by Young et al. [23] in USA. Moreover, a decreasing tree density and basal area in an unmanaged stand was reported by Ediriweera et al. [24] in their study in mixed-dipterocarp forests over a 40-year period.

One possible reason for increasing the $\mathrm{N}$ and BA of forest, including those of high-value timber species, would be due to some major disturbance, including natural (e.g., strong typhoon) and anthropogenic (e.g., selection harvest) factors [26]. In the mixed conifer-broadleaf forest in northern Japan, a large typhoon occurred, causing widespread canopy opening [40] in some plots. Selection harvesting was carried out three to four times during the 48 years period. The increasing trend of both total $\mathrm{N}$ and BA of forest stand was greatly contributed by broadleaf species. These increasing trends in both $\mathrm{N}$ and BA are consistent with previous studies in mixed conifer-broadleaf forests in northern Japan such as that done by Yoshida et al. [18]. Those studies also highlighted the increasing trend of broadleaf tree density in mixed conifer-broadleaf forests managed under selection system.

Reversed J-shaped diameter distributions were observed for all target high-value timber species (Figure 2). Diameter distribution curves indicated an increasing number of smaller diameter class trees for all species across census periods. Owari et al. [35] also reported a large number of smaller diameter class trees in northern Japanese mixed conifer-broadleaf forests. More fluctuation in size structure of monarch birch and Japanese oak were observed.

Similar to N and BA, the mean BAI of high-value timber increased over time. The increasing trend was also observed for the mean stand BAI even though it was not significantly different in the first three census periods. The results of regression modeling suggested temporal trends of BAI for high-value timber species and the total BAI of forest stands. In terms of the stand level BAI, a significant positive trend was observed. In northern mixed conifer-broadleaf forests, similar results have been reported for the broadleaf species (e.g., [18,41]).

The mean N-mor across census periods showed no significant difference for all high-value timber species. However, Japanese oak N-mor increased over time. Furthermore, no significant increasing or decreasing trends in N-rec were observed for high-value timber species across census periods in 
this study. These results are also consistent with previous studies by Hiura et al. [41]. For all target species, a significantly lower N-rec was observed in the first and last census periods, while a higher N-rec was observed in the second, third and fourth census periods. This trend can also be observed for the total N-rec of all species. This pattern may also be explained by a large disturbance caused by a large typhoon in 1981 (second census period) which created a canopy opening causing high light availability [42] in some plots, favoring natural regeneration. As a result, higher N-rec in these plots would be expected following a large natural disturbance. This was also highlighted by previous studies in the mixed conifer-broadleaf forest in Northern Japan. Yoshida et al. [18], for example, reported that a higher N-rec of castor aralia would be expected after a disturbance, and harvesting treatment in their study. In addition, Takahashi et al. [43] reported that Japanese oak may tend to regenerate after a large disturbance before the establishment of other species.

The results in this study also clearly show another important temporal trend of the forest stand. The forest composition and structure in the study area changed over time after the first census period (1968 to 1978). The proportion of conifer in the first census period was $48.35 \%$, and it decreased to $33 \%$ in the last census period. An increasing broadleaf proportion might contribute to an increased $\mathrm{N}$ of high-value timber species (Table 2). Broadleaf $\mathrm{N}$ and BA exceeded those of conifer after the first census period, wherein the $\mathrm{N}$ and BA of conifer were larger than those of broadleaf. Even though there might be several reasons for this, one of the possible reasons for decreased conifer $\mathrm{N}$ and BA would be due to a bias in tree marking for harvesting. Table 6 showed that the total harvested basal area for conifer always exceeds that of broadleaf in all census periods. Owari et al. [36] indicated that even though spatially unbiased tree marking was obtained, tree species that were marked for selection harvest in our study area was mostly conifer species. In addition, they observed that the trees marked for harvesting were larger than the unmarked trees.

In terms of BAI, conifer showed a decreasing trend over time (Table 3). Even though the mean BAI of conifer exceeded the mean BAI of broadleaf throughout the census periods, both were almost similar in the last census period $\left(0.379 \mathrm{~m}^{2} /\right.$ ha for conifer and $0.369 \mathrm{~m}^{2} /$ ha for broadleaf). In addition, the mean BAI of conifer was significantly lower in the last census period than in the first four periods. Yoshida et al. [18] reported that the growth of shade-intolerant broadleaf species was less than that of most common conifer species (i.e., A. sachalinensis), even after selection harvesting. However, our study found that even though a larger mean BAI was observed for all conifer species, its BAI showed a decreasing trend while the total BAI of broadleaf species exhibited increasing trend. Harvesting of more conifer trees may contribute lower mean value in total BAI. Our results are in line with a previous study by Hiura et al. [41] in mixed conifer-broadleaf forest in northern Japan. According to this trend, the future forest composition of the study area would be more of a broadleaf-dominating type in terms of both $\mathrm{N}$ and BA. A similar decreasing trend in the conifer proportion has been reported in different regions $[20,21]$.

The results of the sustainability measures in this study revealed that there have been inconstancies in these measures over time. However, such inconsistencies could relate to a number of reasons. A recent study [41] in mixed conifer-broadleaf forest with very little human disturbance in northern Japan revealed that changing climate conditions such as an increased temperature, precipitation, and decreased snowfall and snow cover period have led a to reduction in growth rate of conifer and an increasing in that of broadleaf species. Moreover, these inconsistencies in sustainability measures due to a changing climate have been widely reported in different regions [44,45]. Similar to the results by $\mathrm{O}^{\prime} \mathrm{Hara}$ et al. [8], the results of this study indicate that a single-tree selection system is more of a dynamic entity.

The sustainability measures described in this study would be useful for adjusting forest management activities, and various silvicultural activities, which could lead to consistency in sustainability measures in different forest types. Through the understanding of sustainability measures used in this study, forest management can maintain the stocking of uneven-aged forest stand over time, BAI can be balanced by tree removals, and recruitment can be assessed whether it is sufficient. In 
addition, it would provide information for forest management operations such as stocking control, which is central to uneven-aged silviculture. Many stocking control approaches have been developed including reversed J-shape diameter distribution, selection system or plenter system, stand density index, and leaf area allocation, etc. [46]. Sustainability measures can be achieved through these stocking control approaches by removing those trees that surpass or maintain those of limited numbers in a certain diameter class.

\section{Conclusions}

In this study, we examined the sustainability of high-value timber species in mixed conifer-broadleaf forest managed under selection system. Changes in the stocking, demographic characteristics, and species proportion of high-value timber species over a 48-year period have been used as measures of sustainability. These measures could provide useful information for their management in the long-run. In addition, we examined the general temporal trend of a selection forest stand. The main common characteristics of high-value timber species were increases in the tree density, basal area, and BAI across the census period. In terms of tree mortality, no significant differences were observed among census periods with no significant downward or upward trends. High fluctuation in the number of in-growth also occurred. Other important long-term characteristics of the forest stands are the changes in forest structure and composition to broadleaf forest in terms of the tree density and basal area. Even though some fluctuations in sustainability measures were observed, the results indicated that sustainability of high-value timber species was achieved under a single-tree selection system. The results of this study would be useful for adapting silvicultural practices and harvesting practices such as single-tree selection, and also to maintain desired stocking of the forest stand. For example, attention should be paid to possible changes in species proportion and diameter distribution of remaining forest stand when marking trees for harvesting. The influence of natural and anthropogenic factors on long-term changes in stocking and demography of high-value timber species should be analyzed further.

Author Contributions: Data analysis, original draft manuscript preparation, K.T.M.; Supervision, review and editing, T.O. All authors have read and agreed to the published version of the manuscript.

Funding: This study was supported by JSPS KAKENHI grant number 17H01516.

Acknowledgments: The authors would like to thank the current and former technical staff of the University of Tokyo Hokkaido Forest for their substantial efforts and contributions in the field measurements of the permanent plots. We thank Hitomi Ogawa at the University of Tokyo Hokkaido Forest for organizing the permanent plot data.

Conflicts of Interest: The authors declare no conflict of interest.

\section{References}

1. Lutz, J.A.; Furniss, T.J.; Johnson, D.J.; Davies, S.J.; Allen, D.; Alonso, A.; Anderson-Teixeira, K.J.; Andrade, A.; Baltzer, J.; Becker, K.M.L.; et al. Global importance of large-diameter trees. Glob. Ecol. Biogeogr. 2018, 27, 849-864. [CrossRef]

2. Vandekerkhovea, K.; Vanhellemont, M.; Vrška, T.; Meyer, P.; Tabaku, V.; Thomaes, A.; Leyman, A.; De Keersmaeker, L.; Verheyen, K. Very large trees in a lowland old-growth beech (Fagus sylvatica L.) forest: Density, size, growth and spatial patterns in comparison to reference sites in Europe. For. Ecol. Manag. 2018, 417, 1-17. [CrossRef]

3. Ali, A.; Lin, S.L.; He, J.K.; Kong, F.M.; Yu, J.H.; Jiang, H.S. Big-sized trees overrule remaining trees' attributes and species richness as determinants of aboveground biomass in tropical forests. Glob. Chang. Biol. 2019, 25, 2810-2824. [CrossRef] [PubMed]

4. Keeton, W.S.; Franklin, J.F. Do remnant old-growth trees accelerate rates of succession in mature Douglas-Fir forests? Ecol. Monogr. 2005, 75, 103-118. [CrossRef]

5. Khai, T.C.; Mizoueb, N.; Kajisa, T.; Otab, T.; Yoshida, S. Stand structure, composition and illegal logging in selectively logged production forests of Myanmar: Comparison of two compartments subject to different cutting frequency. Glob. Ecol. Conserv. 2016, 7, 132-140. [CrossRef] 
6. Bourland, N.; Kouadio, Y.L.; Lejeune, P.; Sonké, B.; Philippart, J.; Daïnou, K.; Fétéké, F.; Doucet, J.-L. Ecology of Pericopsis elata (Fabaceae), an endangered timber species in southeastern Cameroon. Biotropica 2012, 44, 840-847.

7. Lindenmayer, D.B.; Laurance, W.F.; Franklin, J.F.; Likens, G.E.; Banks, S.C.; Blanchard, W.; Gibbons, P.; Ikin, K.; Blair, D.; McBurney, L.; et al. New policies for old trees: Averting a global crisis in a keystone ecological structure. Conserv. Lett. 2013, 7, 61-69. [CrossRef]

8. O'Hara, K.L.; Hasenauer, H.; Kindermann, G. Sustainability in multi-aged stands: An analysis of long-term plenter systems. Forestry 2007, 80, 163-181. [CrossRef]

9. Kuuluvainen, T.; Tahvonen, O.; Aakala, T. Even-aged and uneven-aged forest management in boreal fennoscandia: A review. Ambio 2012, 41, 720-737. [CrossRef]

10. Laiho, O.; Lähde, E.; Pukkala, T. Uneven-vs even-aged management in Finnish boreal forests. Forestry 2011, 84, 547-556. [CrossRef]

11. Pukkala, T.; Lähde, E.; Laiho, O.; Salo, K.; Hotanen, J.-P. A multifunctional comparison of even-aged and uneven-aged forest management in a boreal region. Can. J. For. Res. 2011, 41, 851-862. [CrossRef]

12. Puettmann, K.J.; Wilson, S.M.; Baker, S.C.; Donoso, P.J.; Drössler, L.; Amente, G.; Harvey, B.D.; Knoke, T.; Lu, Y.; Nocentini, S.; et al. Silvicultural alternatives to conventional even-aged forest management-What limits global adoption? For. Ecosyst. 2015, 2, 1-16. [CrossRef]

13. MacDicken, K.G.; Sola, P.; Hall, J.E.; Sabogal, C.; Tadoum, M.; de Wasseige, C. Global progress toward sustainable forest management. For. Ecol. Manag. 2015, 352, 47-56. [CrossRef]

14. Dieler, J.; Uhl, E.; Biber, P.; Müller, J.; Rötzer, T.; Pretzsch, H. Effect of forest stand management on species composition, structural diversity, and productivity in the temperate zone of Europe. Eur. J. For. Res. 2017, 136, 739-766. [CrossRef]

15. Schütz, J.P.; Saniga, M.; Diaci, J.; Vrška, T. Comparing close-to-nature silviculture with processes in pristine forests: Lessons from Central Europe. Ann. For. Sci. 2016, 73, 911-921. [CrossRef]

16. O'Hara, K.L. What is close-to-nature silviculture in a changing world? Forestry 2016, 89, 1-6. [CrossRef]

17. Yasuda, A.; Yoshida, T.; Miya, H.; Harvey, B.D. An alternative management regime of selection cutting for sustaining stand structure of mixed forests of northern Japan: A simulation study. J. For. Res. 2013, 18, 398-406. [CrossRef]

18. Yoshida, T.; Noguchi, M.; Akibayashi, Y.; Noda, M.; Kadomatsu, M.; Sasa, K. Twenty years of community dynamics in a mixed conifer-broad-leaved forest under a selection system in northern Japan. Can. J. For. Res. 2006, 36, 1363-1375. [CrossRef]

19. Amaral, M.R.M.; Lima, A.J.N.; Higuchi, F.G.; dos Santos, J.; Higuchi, N. Dynamics of tropical forest twenty-five years after experimental logging in central amazon mature forest. Forests 2019, 10, 89. [CrossRef]

20. Klopcic, M.; Boncina, A. Stand dynamics of silver fir (Abies alba Mill.)-European beech (Fagus sylvatica L.) forests during the past century: A decline of silver fir? Forestry 2011, 84, 259-271. [CrossRef]

21. Schuler, T.M. Fifty years of partial harvesting in a mixed mesophytic forest: Composition and productivity. Can. J. For. Res. 2004, 34, 985-997. [CrossRef]

22. Poudyal, B.H.; Maraseni, T.; Cockfield, G. Impacts of forest management on tree species richness and composition: Assessment of forest management regimes in Tarai landscape Nepal. Appl. Geogr. 2019, 111, 102078. [CrossRef]

23. Young, B.D.; D'Amato, A.W.; Kern, C.C.; Kastendick, D.N.; Palik, B.J. Seven decades of change in forest structure and composition in Pinus resinosa forests in northern Minnesota, USA: Comparing managed and unmanaged conditions. For. Ecol. Manag. 2017, 395, 92-103. [CrossRef]

24. Ediriweera, S.; Bandara, C.; Woodbury, D.J.; Mi, X.; Gunatilleke, I.A.U.N.; Gunatilleke, C.V.S.; Ashton, M.S. Changes in tree structure, composition, and diversity of a mixed-dipterocarp rainforest over a 40-year period. For. Ecol. Manag. 2020, 458, 117764. [CrossRef]

25. Miya, H.; Yoshida, T.; Noguchi, M.; Nakamura, F. Individual growing conditions that affect diameter increment of tree saplings after selection harvesting in a mixed forest in northern Japan. J. For. Res. 2009, 14, 302-310. [CrossRef]

26. Noguchi, M.; Yoshida, T. Individual-scale responses of five dominant tree species to single-tree selection harvesting in a mixed forest in Hokkaido, northern Japan. J. For. Res. 2009, 14, 311-320. [CrossRef] 
27. Tatsumi, S.; Owari, T.; Kasahara, H.; Nakagawa, Y. Individual-level analysis of damage to residual trees after single-tree selection harvesting in northern Japanese mixedwood stands. J. For. Res. 2014, 19, 369-378. [CrossRef]

28. Yoshida, T.; Noguchi, M. Growth and survival of Abies sachalinensis seedlings for three years after selection harvesting in northern Hokkaido, Japan. Landsc. Ecol. Eng. 2010, 6, 37-42. [CrossRef]

29. Müller, S.; Ammer, C.; Nüsslein, S. Analyses of stand structure as a tool for silvicultural decisions-A case study in a Quercus petraea-Sorbus torminalis stand. Forstwiss. Cent. 2000, 119, 32-42. [CrossRef]

30. Kuuluvainen, T. Natural variability of forests as a reference for restoring and managing biological diversity in boreal Fennoscandia. Silva Fenn. 2002, 36, 97-125. [CrossRef]

31. Schall, P.; Schulze, E.D.; Fischer, M.; Ayasse, M.; Ammer, C. Relations between forest management, stand structure and productivity across different types of Central European forests. Basic Appl. Ecol. 2018, 32, 39-52. [CrossRef]

32. Pretzsch, H.; del Río, M.; Biber, P.; Arcangeli, C.; Bielak, K.; Brang, P.; Dudzinska, M.; Forrester, D.I.; Klädtke, J.; Kohnle, U.; et al. Maintenance of long-term experiments for unique insights into forest growth dynamics and trends: Review and perspectives. Eur. J. For. Res. 2019, 138, 165-185. [CrossRef]

33. Owari, T.; Okamura, K.; Fukushi, K.; Kasahara, H.; Tatsumi, S. Single-tree management for high-value timber species in a cool-temperate mixed forest in northern Japan. Int. J. Biodivers. Sci. Ecosyst. Serv. Manag. 2016, 12, 74-82. [CrossRef]

34. Owari, T. Relationships between the abundance of Abies sachalinensis juveniles and site conditions in selection forests of Central Hokkaido, Japan. Formath 2013, 12, 1-20. [CrossRef]

35. Owari, T.; Matsui, M.; Inukai, H.; Kaji, M. Stand structure and geographic conditions of natural selection forests in central Hokkaido, northern Japan. J. For. Plan. 2011, 16, 207-214.

36. Owari, T.; Inukai, H.; Koike, Y.; Minowa, Y.; Nakajima, T. Single-tree selection techniques in the stand-based forest management system. Trans. Meet. Hokkaido Branch Jpn. For. Soc. 2010, 58, 101-104. (In Japanese)

37. Owari, T. Sustainable and adaptive forest management and data infrastructure under the stand-based silvicultural system. Proc. Inst. Stat. Math. 2013, 61, 201-216. (In Japanese)

38. Ishibashi, S.; Hirokawa, T. An analysis of data on selection forest in the Tokyo University Forest in Hokkaido. Trans. Annu. Meet. Kanto Branch Jpn. For. Soc. 1986, 37, 15-18. (In Japanese)

39. R Core Team. R: The R Project for Statistical Computing; R Foundation for Statistical Computing: Vienna, Austria, 2019; Available online: https://www.r-project.org/ (accessed on 6 January 2020).

40. Yoshida, T.; Noguchi, M. Vulnerability to strong winds for major tree species in a northern Japanese mixed forest: Analyses of historical data. Ecol. Res. 2009, 24, 909-919. [CrossRef]

41. Hiura, T.; Go, S.; Iijima, H. Long-term forest dynamics in response to climate change in northern mixed forests in Japan: A 38-year individual-based approach. For. Ecol. Manag. 2019, 449, 117469. [CrossRef]

42. Ishikawa, Y.; Ito, K. The regeneration process in a mixed forest in central Hokkaido, Japan. Vegetatio 1988, 79, 75-84. [CrossRef]

43. Takahashi, K.; Mitsuishi, D.; Uemura, S.; Suzuki, J.I.; Hara, T. Stand structure and dynamics during a 16-year period in a sub-boreal conifer-hardwood mixed forest, northern Japan. For. Ecol. Manag. 2003, 174, 39-50. [CrossRef]

44. McMahon, S.M.; Parker, G.G.; Miller, D.R. Evidence for a recent increase in forest growth. Proc. Natl. Acad. Sci. USA 2010, 107, 3611-3615. [CrossRef] [PubMed]

45. Pretzsch, H.; Biber, P.; Schütze, G.; Uhl, E.; Rötzer, T. Forest stand growth dynamics in Central Europe have accelerated since 1870. Nat. Commun. 2014, 5, 4967. [CrossRef] [PubMed]

46. O'Hara, K.L.; Gersonde, R.F. Stocking control concepts in uneven-aged silviculture. Forestry 2004, 77, 131-143. [CrossRef]

(C) 2020 by the authors. Licensee MDPI, Basel, Switzerland. This article is an open access article distributed under the terms and conditions of the Creative Commons Attribution (CC BY) license (http://creativecommons.org/licenses/by/4.0/). 